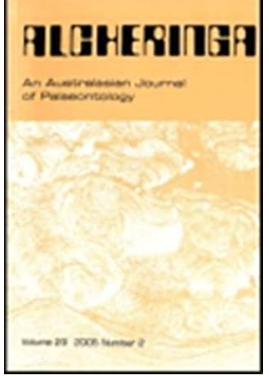

\title{
New records of the hypercalcified sponge Plectroninia (Calcarea, Minchinellidae) in the Recent deep ocean
}

\begin{tabular}{|r|l|}
\hline Journal: & Alcheringa \\
\hline Manuscript ID & TALC-2017-0006.R1 \\
\hline Manuscript Type: & Standard Research Article \\
\hline Date Submitted by the Author: & n/a \\
\hline Complete List of Authors: & $\begin{array}{l}\text { Vacelet, Jean; Institut mediterraneen de biodiversite et d'ecologie marine } \\
\text { et continentale, } \\
\text { James, Benjamin; Station marine d'Endoume } \\
\text { Zibrowius, Helmut; Station marine d'Endoume, chemin de la Batterie des } \\
\text { Lions }\end{array}$ \\
\hline Keywords: & Porifera, Minchinellidae, Bathyal Zone, Lithonida, Calcareous sponges \\
\hline & \multicolumn{2}{|l}{} \\
\hline
\end{tabular}

\section{SCHOLARONE ${ }^{m}$}

Manuscripts 
New records of the hypercalcified sponge Plectroninia (Calcarea, Minchinellidae) in the Recent deep ocean

\begin{abstract}
Numerous small specimens of hypercalcified sponges of the genus Plectroninia (Jurassic to Recent) are recorded from deep water in the Atlantic, Indian and Pacific oceans, where they are attached to diverse hard substrata, mostly scleractinian skeletons. Being represented as skeletons of linked calcareous tetractines with an incomplete free spicule complement the specimens could not be identified at the species level. These observations show that Plectroninia spp. have a wide distribution in the bathyal zone of the Recent World Ocean, where they may be the most common calcareous sponges.
\end{abstract}

Keywords: Porifera; calcareous sponges; bathyal zone; Minchinellidae; Lithonida.

\title{
Introduction
}

Minchinellidae Dendy \& Row, 1913 (Calcarea, Lithonida) is a family of calcareous sponges well represented in the fossil record among the "pharetronids"-a polyphyletic group of hypercalcified sponges now classified in diverse taxa of Calcarea and for some of them even in Demospongiae. In the Mesozoic, hypercalcified sponges were significant reef-builders. However, in the Recent, there are a few remnant survivors which have often been considered as relicts. The family Minchinellidae is characterized by a skeleton of tetractine spicules linked together in a rigid structure (Vacelet et al. 2002, Vacelet 2012). ). In this family, the genus Plectroninia Hinde, 1900 was first described in the fossil record as P. halli Hinde, 1900 from Australia, then considered as Eocene but now dated to Early and Middle Miocene (Pickett 1983). After its description as fossil, the genus has been found in the Recent by Kirkpatrick (1900, 1911), who described two species from $90 \mathrm{~m}$ depth from the tropical Indo-Pacific. Subsequently, more species have been described from present-day seas, and of the 13 species presently known in the Recent, most occur in dark submarine caves of the tropical Indopacific and the Mediterranean (Vacelet 2012). First bathyal records (down to $1600 \mathrm{~m}$ ) were from the north Atlantic and the Mediterranean (Könnecker 1989, Vacelet et al. 1989, Könnecker \& Freiwald 2005. The diagnosis of the genus Plectroninia in Systema Porifera is: Minchinellidae with a basal skeleton made up of two types of fused tetractines, a layer composed of large tetractines and a layer of small tetractines. Tetractines fused by their basal actines, with the apical actine remaining free and pointing outwards. Basal actines attached by simple zygosis in small tetractines, zygosis reinforced by a cement layer in large tetractines. Cortical skeleton of free spicules tangentially arranged (Vacelet et al. 2002).

Our additional new records throughout the World Ocean confirm the wide distribution of the genus Plectroninia and show that it should no longer be considered as a rare relict or a refugee group in present-day seas.

The new samples presented here were mostly found on coral skeletons collected in various areas of the World Ocean and mostly from bathyal depths (Table 1). The samples are reduced to the rigid skeleton and do not include the free spicules. Accordingly, they cannot be identified at the species level. Nevertheless, this unique 
collection is of great interest by widely improving our knowledge of Plectroninia spp. in the Recent.

\section{Material and methods}

The collection of Plectroninia resulted from sorting samples taken during various oceanographic cruises (Table 1), mostly by dredging, occasionally by picking up from a submersible. In order to identify scleractinians, corals were often treated with hot sodium hypochlorite solution which contributed to making small calcified epifauna more evident. Tiny Plectroninia were thus easier to recognize than on the raw material where they are commonly concealed by trapped sediment or, when already dead, overgrown by "soft" sponge crusts.

However, the living tissue and free spicules of the dermal layer were lost during the bleach treatment, and the specimens, in most cases reduced to the basal skeleton of linked spicules, could not be identified or described to the species level. The specimens were observed and photographed under a binocular microscope. Some were sputter-coated with gold-palladium and observed under a Hitachi S570 scanning electron microscope.

The Plectroninia collection has been deposited as a whole in the Porifera collection of Muséum National d'Histoire Naturelle, Paris, number MNHN-IP-20151480 to 1543 .

\section{Results}

All specimens are small encrustations, roughly circular, with a minimum size of $0.5 \mathrm{x}$ $0.5 \mathrm{~mm}$, and up to $5 \times 6 \mathrm{~mm}$ (Figs.1-3). The number of specimens found by sampling sites was variable according to the number of corals skeletons that were examined. In most sites, there was a single specimen. However, up to 24 specimens were found in a New Caledonia site (Alis Musorstom 6, DW 400, 14/02/1989). A total number of 109 specimens was found. Most are reduced to a well preserved basal skeleton composed of two layers of tetractines fused or intermingled by their basal actines with the apical actine free and pointing outward. The basal layer, generally well visible near the edge of the crust, is made of small tetractines, and is covered by a layer of larger tetractines, conforming to the typical structure of the Recent species in the genus Plectroninia (Figs 1-3). In a few cases, some free spicules from the dermal layer and choanosome, diactines, triactines, and tuning fork (diapasons) triactines, remain intermingled with the linked tetractines. Some specimens, already dead when sampled, show an eroded, poorly preserved basal skeleton. Siliceous skeletons of encrusting lithistids, also present on some of the substrates, are easily distinguished from the calcareous Plectroninia skeletons.

Size and skeleton characters (in particular spicule ornamentation) show some variation. The free apical actine of the large tetractines is generally smaller than 200 $\mu \mathrm{m}$, with a maximum length of $234 \mu \mathrm{m}$ observed in a specimen from New Caledonia. These free actines may be nearly smooth with only a few spines near the base, or bear a variable number of short, conical spines, arranged in rows in a specimen from La Réunion (Fig. 2D). The basal actines have more numerous conical spines, also frequently in rows, and are linked together by enlarged ends (Figs. 1C \& D, 2B \& F, $3 \mathrm{~B}, \mathrm{E} \& \mathrm{~F}$ ). Growth stages of these tetractines are observed in some specimens (see, 
for example Fig. 3B). The small tetractines are more heavily spined, with spines sometimes nearly as large as the free apical actine and bearing a secondary spination. In some individuals the underside of the sponge could be seen and shows that it was attached to the substrate by the enlarged ends of the basal actines of the small tetractines (Figs. 2D, 3F).

\section{Discussion}

The samples here can be identified with the genus Plectroninia as it is conventionally understood while the placement of these Recent forms in the same genus with the fossil Plectroninia halli (type of the genus) is pending, awaiting a revision of other fossil genera in the Minchinellidae (Finks et al. 2011, Vacelet 2012). In some cases, the basal skeleton is eroded and poorly preserved, making the identification as Plectroninia less certain. However, the preservation is good enough to prevent confusion with other Recent genera of Minchinellidae. Petrostroma Döderlein, 1892 and Minchinella Kirkpatrick, 1908 are erect rather than encrusting. Petrostroma is known from a single record from the upper bathyal in the tropical Pacific and has a rigid skeleton forming radial lines (Vacelet 2012), a feature absent in all our specimens. Minchinella has a rigid skeleton made of a single category of large tetractines partly embedded in a cement, whereas all our specimens have linked tetractines of two size classes and are devoid of embedding cement. In Monoplectroninia Pouliquen \& Vacelet, 1970, from Mediterranean submarine caves, the rigid skeleton consists of a single type of small tetractines. In Tulearinia Vacelet, 1977 the rigid skeleton is feebly linked and would not resist the drastic cleaning by sodium hypochlorite.

Being mostly reduced to the basal rigid skeleton, without the free spicules of the choanosome and dermal layer, our specimens cannot be identified to any of the 13 known Recent species listed in World Porifera Database (Van Soest et al. 2015), for which a comparative table of spicules has been given by Könnecker et Freiwald 2005. However, the differences in size and spination of the tetractines of the basal skeleton indicate that several species are present, as implied by the worldwide provenance of the material. Only two species, $P$. celtica Könnecker \& Freiwald, 2005 and $P$. norvegica Könnecker, 1989 have been specifically identified in the bathyal zone of a single area (the North-East Atlantic) and it is obvious that the diversity of bathyal Plectroninia spp. can be expected to be higher in the World Ocean. We observed a maximum length of $234 \mu \mathrm{m}$ for the free apical actine, indicating that we did not find $P$. norvegica which is characterized by distinctly larger actines up to $500 \mu \mathrm{m}$ long.

The presence of calcareous sponges of the Class Calcarea in the deep sea has been underestimated for a long time (Rapp et al. 2011). In fact they are more common than formerly expected and our data suggest that the genus Plectroninia may be one of the most common Calcarea in the bathyal zone, worldwide. Being minute and having the dermal layer often covered by mud, they are easily overlooked when deep sea material is sorted, whether they incrust hard substrates or live loose on muddy sand (Könnecker 1989). However, their rigid basal skeleton of fused or linked spicules (apt for fossilization) can withstand drastic cleaning and thus becomes more easily visible. The cleaning technique that we used here reveals that these sponges may be very common in the deep sea, with a very large distribution in bathyal depths. Presently, the maximum depth record of Plectroninia is $1644 \mathrm{~m}$ on the Vavilov Seamount in the 
Western Mediterranean (Table 1), with other remarkably deep records to $1600 \mathrm{~m}$ from the western Mediterranean (Vacelet et al. 1989) and other remarkably deep records to $1269 \mathrm{~m}$ and $1391 \mathrm{~m}$ from the eastern Mediterranean basin (Ilan et al. 2003), i.e., in a sea that is commonly considered as having a poor deep-sea fauna.

The absence of locations in wide areas of the World Ocean in our distribution map (Fig. 4) should not be interpreted as presenting the reality of Plectroninia distribution. We did not have access to potential substrates from all areas. We also admit that our records may be biased by more attention having been given to tiny epifauna in one coral collection than in another, according to circumstances (need to having a collection treated fast or not, diversity of the components, quantity, etc.).

Due to sampling bias, our records are more frequent in certain areas, for instance around New Caledonia, a region covered by many cruises which provided an exceptionally large quantity and diversity of bathyal scleractinian corals. Of particular interest are the records from Barbados and Brazil, Tropical Western Atlantic. No representative of Minchinellidae was previously recorded from this area where submarine caves are famous for the fauna of hypercalcified demosponges ("Sclerosponges") as in Jamaica (Hartman \& Goreau 1970).

Our observations suggest that minute Plectroninia spp. are the most common calcareous sponges in the Recent bathyal environment. It is not clear if this was the case also in the geological past. Minchinellidae have been considered as rather shallow in Eocene strata (Finks et al. 2011), but this was mostly based on the obsolete idea that in the Present Calcarea are confined to depths shallower than $60 \mathrm{~m}$. This assumption has already been questioned (Borojevic \& Graat-Kleeton 1965, Vacelet 1988, Janusssen et al. 2003, Rapp et al. 2011). We now have reasons to consider the fossil Minchinellidae as a relatively deep-water group, thriving at sub-photic depths as suggested for Porosphaera, a genus common in the fossil record, and other Minchinellidae from the Cretaceous (Nestler 1961 \& 1965, Reitner 1992, Wilmsen et al. 2012). In more recent times, in the Upper Miocene (Messinian), Plectroninia is clearly a member of a diversified upper bathyal assemblage (Barrier et al. 1991).

Table 1: Collection data of the specimens.

Fig. 1: A-D: Specimen from Brazil, $217 \mathrm{~m}$ depth. Note the presence of a tuning fork triactine in D (arrow). E-F: specimen from Azores, $914 \mathrm{~m}$ depth.

Fig. 2: A-D: Specimen from La Réunion, $470-540 \mathrm{~m}$ depth. B and C show some preserved free spicules, including a tuning fork triactine in $\mathrm{C}$ (arrow). D is a view of the underside, showing the attachment of the small tetractines by an enlarged ends on the substratum. E-F: specimen from New Caledonia, $270 \mathrm{~m}$ depth.

Fig. 3: A-C: Specimen from New Caledonia, $360 \mathrm{~m}$ depth. In B, presence of a tuning fork triactine and of a growing stage of large triactine (arrows). D-F: other specimen from New Caledonia, $360 \mathrm{~m}$ depth. In A \& D, an area of the underside detached from the substratum.

Fig. 4: Localization of the new records of Plectroninia.

\section{References}

BARRIER, P., ZIBROWIUS, H., LOZOUET, P., MONTENAT, C., OTT D'ESTEVOU, P., SERRANO, F. \& SOUDET, H.J., 1991. Une faune de fond dur du bathyal supérieur dans le Miocène terminal des Cordillères bétiques (Carboneras, SE Espagne). Mésogée 51, 3-13. 
BOROJEVIC, R. \& GRAAT-KLEETON, G., 1965. Sur une nouvelle espèce de Sycon et quelques Démosponges récoltées par le "Cirrus" dans l'Atlantique Nord. Beaufortia 13, 8185 .

DÖDERLEIN, L., 1892.Über Petrostroma schulzei, n. g., n. sp. der Kalkschwämme. Verhandlungen der Deutschen Zoologischen Gesellschaft in Heidelberg 2, 143-145.

FINKS, R.M., HOLLOCHER, K. \& THIES, K.J., 2011. A major Eocene sponge fauna (Castle Hayne Formation, North Carolina). Journal of the North Carolina Academy of Science $127,39-175$.

HINDE, G.J., 1900. On some remarkable Calcisponges from the Eocene strata of Victoria (Australia). Quarterly Journal of the Geological Society of London 56, 50-66.

ILAN, M., GUGEL, J., GALIL B.S. \& JANUSSEN, D., 2003. Small bathyal sponge species from East Mediterranean revealed by a non-regular soft bottom sampling technique. Ophelia $57,145-160$.

JANUSSEN, D., RAPP, H.T. \& TENDAL, O.S., 2003. A myth vanished, calcareous sponges are alive and well at abyssal depths. Deep-Sea Newsletter 32, 17-19.

KIRKPATRICK R., 1900. Description of sponges from Funafuti. The Annals and Magazine of Natural History 34, 345-363.

KIRKPATRICK, R., 1908. On two new genera of recent Pharetronid sponges. The Annals and Magazine of Natural History 2, 503-514.

KIRKPATRICK, R., 1911. On a new Lithonine sponge from Christmas Island. The Annals and Magazine of Natural History 8, 177-179.

KÖNNECKER G., 1989. Plectroninia norvegica sp. nov. (Calcarea, Minchinellidae), a new pharetronid sponge from the North Atlantic. Sarsia 74, 131-135.

KÖNNECKER, G. \& FREIWALD, A., 2005. Plectroninia celtica sp. nov. (Calcarea, Minchinellidae), a new species of "Pharetronid" sponge from bathyal depths in the northern Porcupine Seabight, NE Atlantic. Facies 51, 53-59.

NESTLER, H., 1961. Spongien aus der weissen Schreibkreide (Unteres Maastricht) der Insel Rügen (Ostsee) [Sponges from the White Chalk (Lower Maastrichtian) of the island of Rügen (Baltic Sea)]. Paläontologische Abhandlungen 1, 1-70.

NESTLER, H., 1965. Die Rekonstruktion des Lebensraumes der Rügener SchreibkreideFauna (Unter-Maastricht) mit Hilfe der Paläoökologie und Paläobiologie. Beiheft zur Zeitschrift Geologie 49, 1-147.

PICKETT, J., 1983. An annotated bibliography and review of Australian fossil sponges. Memoirs of the Association of Australasian Palaeontologists 1, 93-120.

POULIQUEN, L. \& VACELET, J., 1970. Nouvelles observations sur des Eponges Pharétronides Minchinellidae de Méditerranée. Téthys 2 (2), 437-442. 
RAPP, H.T., JANUSSEN, D. \& TENDAL, O.S., 2011. Calcareous sponges from abyssal and bathyal depths in the Weddell Sea, Antarctica. Deep-Sea Research II 58, 58-67.

REITNER, J., 1992. "Coralline Spongien". Der Versuch einer phylogenetisch-taxonomischen Analyse. Berliner Geowissenschaftliche Abhandlungen 1, 1-352.

VACELET, J., 1977. Eponges Pharétronides actuelles et Sclérosponges de Polynésie Française, Madagascar et de La Réunion. Bulletin du Muséum National d'Histoire Naturelle, Paris 444, 345-366.

VACELET, J., 1988. Indications de profondeur données par les Spongiaires dans les milieux benthiques actuels. Géologie Méditerranéenne 15, 13-26.

VACELET, J., BOROJEVIC, R., BOURY-ESNAULT, N. \& MANUEL, M., 2002. Order Lithonida. In Systema Porifera, A Guide to the Classification of Sponges. HOOPER J.N.A. \& SOEST R.W.M.van (eds), Kluwer Academic/Plenum Publishers, New York, 1185-1192.

VACELET, J., 2012. Hypercalcified Extant Calcarea. In Treatise on Invertebrate Paleontology On line, Part E (Revised). SELDEN P.A. ed., Volume 4, Hypercalcified Porifera. The University of Kansas, Paleontological Institute, Lawrence (Kansas, USA), Chapter 4C, 1-15.

VACELET, J., BOURY-ESNAULT, N. \& ZIBROWIUS, H , 1989. Unexpected deep-water records of calcareous sponges (Calcarea). Deep-Sea Newsletter 15, 24-25.

Van Soest, R.W.M, Boury-Esnault, N., Hooper, J.N.A., Rützler, K., de Voogd, N.J., Alvarez de Glasby, B., Hajdu, E., Pisera, A.B., Manconi, R., Schoenberg, C., Janussen, D., Tabachnick, K.R., Klautau, M., Picton, B., Kelly, M., Vacelet, J., Dohrmann, M., Díaz, M.C., Cárdenas, P. 2015, World Porifera database. Accessed at http,//www.marinespecies.org/porifera on 2015-11-12

WILMSEN, M., FURSICH, F.T. \& MAJIDIFARD, M.R., 2012. Porosphaera globularis (Phillips, 1829) (Porifera, Calcarea) from the Maastrichtian of the Farokhi Formation of Central Iran. Cretaceous Research 33, 91-96. 

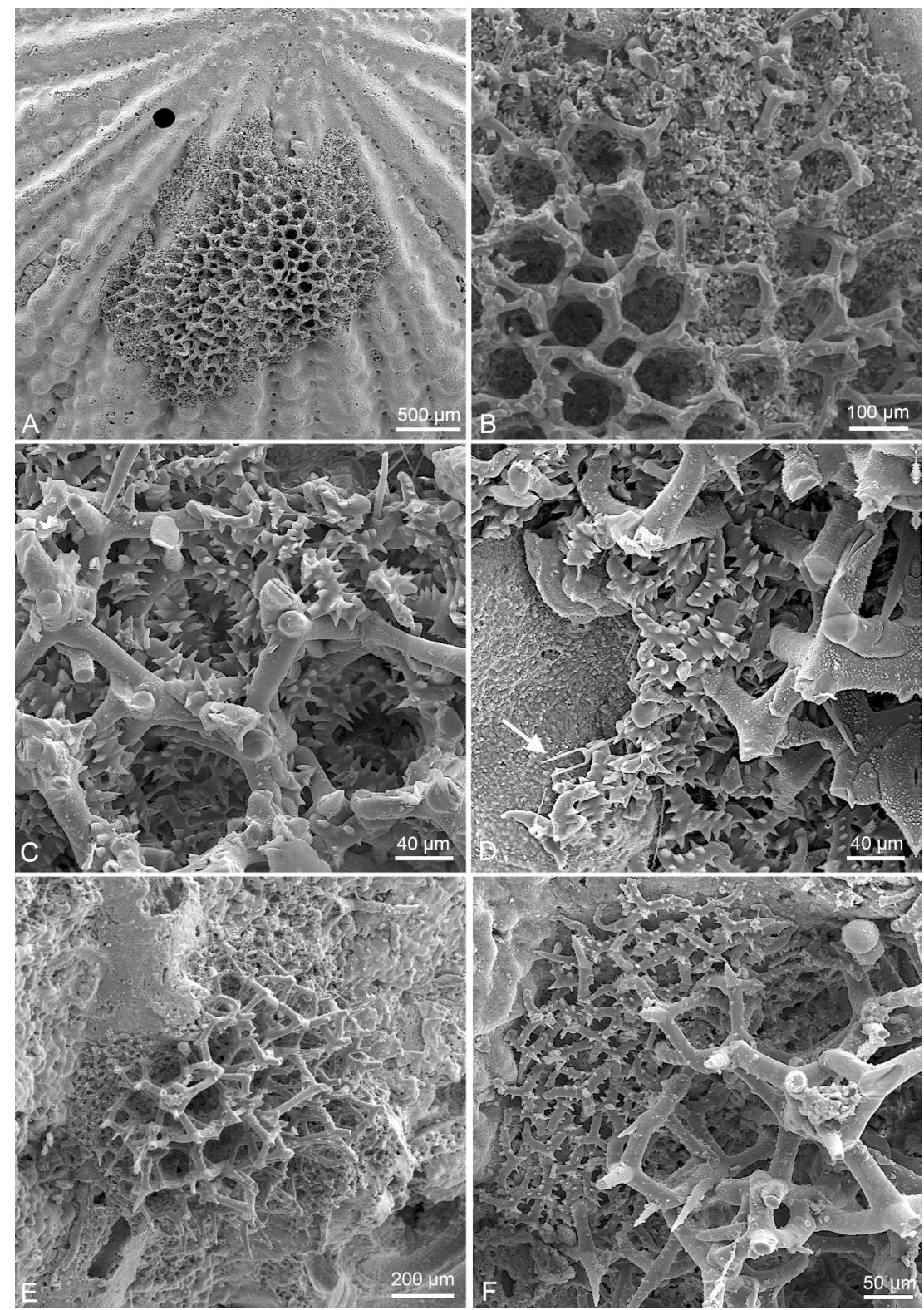

Fig. 1: A-D: Specimen from Brazil, $217 \mathrm{~m}$ depth. Note the presence of a tuning fork triactine in $\mathrm{D}$ (arrow). $\mathrm{E}-\mathrm{F}$ : specimen from Azores, $914 \mathrm{~m}$ depth.

$241 \times 346 \mathrm{~mm}(300 \times 300 \mathrm{DPI})$ 
Fig. 2: A-D: Specimen from La Réunion, 470-540 m depth. B and C show some preserved free spicules, including a tuning fork triactine in $C$ (arrow). D is a view of the underside, showing the attachment of the small tetractines by an enlarged ends on the substratum. E-F: specimen from New Caledonia, $270 \mathrm{~m}$ depth. $168 \times 241 \mathrm{~mm}(300 \times 300 \mathrm{DPI})$ 


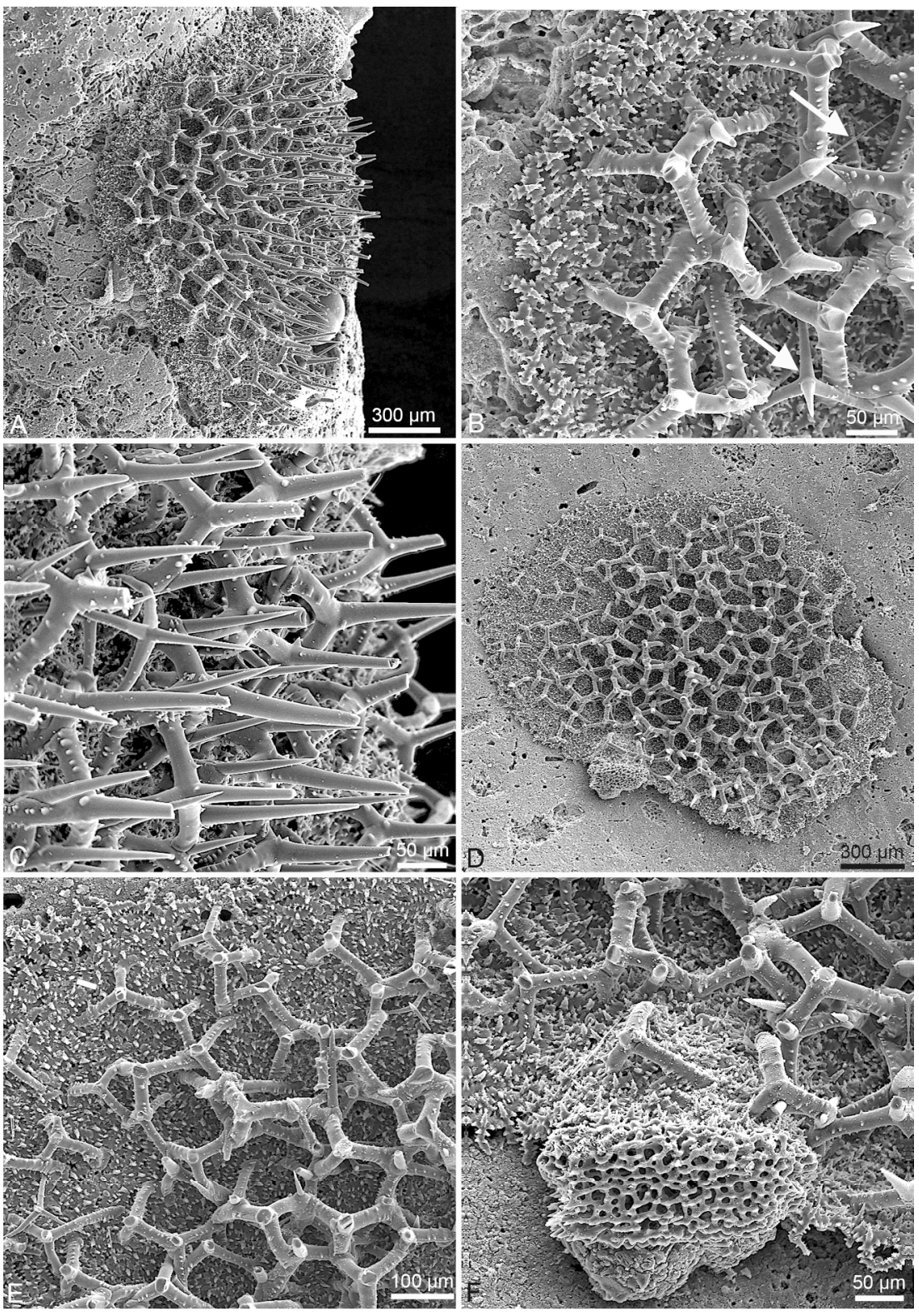

Fig. 3: A-C: Specimen from New Caledonia, $360 \mathrm{~m}$ depth. In B, presence of a tuning fork triactine and of a growing stage of large triactine (arrows). D-F: other specimen from New Caledonia, $360 \mathrm{~m}$ depth. In A \& D, an area of the underside detached from the substratum.

$$
168 \times 241 \mathrm{~mm}(300 \times 300 \mathrm{DPI})
$$




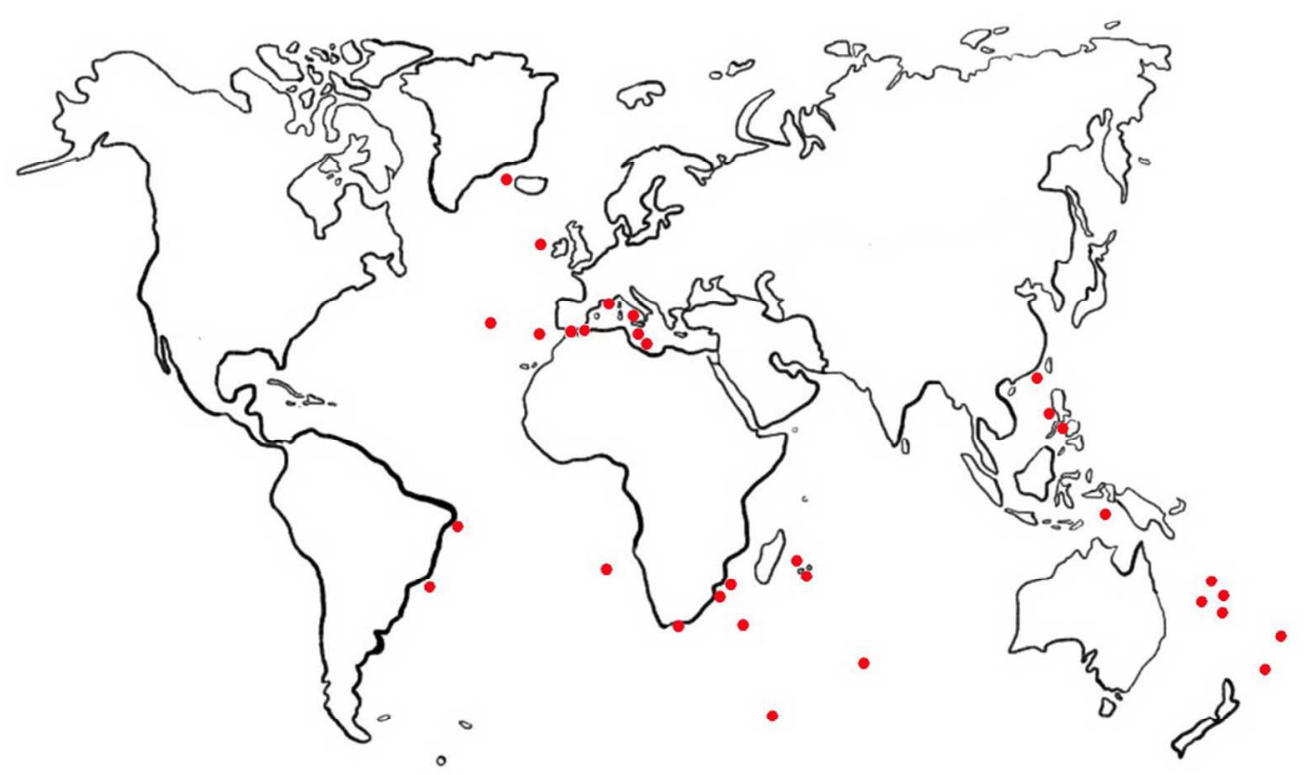

Fig. 4: Localization of the new records of Plectroninia.

$376 \times 281 \mathrm{~mm}(72 \times 72 \mathrm{DPI})$ 


\begin{tabular}{|c|c|c|c|c|c|}
\hline Ship-Cruise & Station & Date & Depth (m) & Lat-Long & Area \\
\hline (on land) & \multicolumn{3}{|c|}{ (Messinian fossil) } & Carboneras & SE Spain \\
\hline Cryos Balgim & DW152 & $17 / 06 / 1984$ & $534-560$ & $35^{\circ} 56.7^{\prime} \mathrm{N}-5^{\circ} 34.7^{\prime} \mathrm{W}$ & Gibraltar \\
\hline Cryos Balgim & DW128 & $14 / 6 / 1984$ & 480 & $35^{\circ} 35.3^{\prime} \mathrm{N}-3^{\circ} 45.1^{\prime} \mathrm{W}$ & Alboran Sea \\
\hline Capricorne Biomede1 & BS 15 & $28 / 8 / 1976$ & 1600 & $42^{\circ} 53^{\prime} \mathrm{N}-6^{\circ} 10^{\prime} \mathrm{E}$ & NW Mediterranean \\
\hline Antedon & dredge & $9 / 1 / 1971$ & 180 & $43^{\circ} 08^{\prime} \mathrm{N}-5^{\circ} 32^{\prime} \mathrm{E}$ & NW Mediterranean \\
\hline Antedon & dive & $25 / 9 / 1992$ & 21 & La Ciotat, cave & NW Mediterranean \\
\hline Le Suroit Marco & $\mathrm{DR} 46$ & $28 / 7 / 1995$ & 1150 & $43^{\circ} 43.20^{\prime} \mathrm{N}-9^{\circ} 18.09^{\prime} \mathrm{E}$ & NW Corsica \\
\hline Sonne SO-41 & $\mathrm{DC} 123$ & $16 / 3 / 1986$ & 1644 & $39^{\circ} 56.24^{\prime} \mathrm{N}-12^{\circ} 37.80^{\prime} \mathrm{E}$ & Vavilov Seamount, NW Med. \\
\hline Urania CS-96 & 157 & $31 / 12 / 1996$ & 257 & $36^{\circ} 29^{\prime} 04^{\prime \prime} \mathrm{N}-12^{\circ} 56^{\prime} 00^{\prime \prime} \mathrm{E}$ & Sicily Strait \\
\hline Calypso & 1902 & $4 / 1965$ & 150 & $32^{\circ} 42^{\prime} \mathrm{N}-14^{\circ} 14^{\prime} \mathrm{E}$ & Libya \\
\hline Bioce & 2692 & $31 / 8 / 1994$ & 1162 & $64^{\circ} 26.60^{\prime} \mathrm{N}-28^{\circ} 15.50^{\prime} \mathrm{W}$ & SW Iceland \\
\hline Heliotrope & trawl & $4 / 1989$ & 1100 & $52^{\circ} 50^{\prime} \mathrm{N}-15^{\circ} \mathrm{W}$ & W Ireland \\
\hline Victor Hensen VH97 & 79 & $21 / 4 / 1997$ & 359 & $36^{\circ} 34.7^{\prime} \mathrm{N}-11^{\circ} 00^{\prime} \mathrm{W}$ & Gorringe Seamount \\
\hline Le Suroit Seamount-1 & DE95 & $11 / 10 / 1987$ & 270 & $35^{\circ} 04.6^{\prime} \mathrm{N}-12^{\circ} 55.3^{\prime} \mathrm{W}$ & Ampere Seamount \\
\hline Cryos Balgim & DW 43 & $2 / 6 / 1984$ & 150 & $35^{\circ} 54.1^{\prime} \mathrm{N}-6^{\circ} 14.5^{\prime} \mathrm{W}$ & Lusit anian Bight \\
\hline Jean Charcot Biaçores & ? & 1971 & $500-900$ & ? & Azores \\
\hline Jean Charcot Gibraco & $\mathrm{DR} 21$ & $8 / 1972$ & 914 & $38^{\circ} 35.07^{\prime} \mathrm{N}-30^{\circ} 40.05^{\prime} \mathrm{W}$ & Azores \\
\hline P.W.Hummel inck & 1443 & 19.2 .1964 & 200 & $13^{\circ} 11^{\prime} \mathrm{N}-59^{\circ} 39^{\prime} \mathrm{W}$ & Barbados \\
\hline Akaroa & $5 \mathrm{C}$ & $10 / 9 / 1965$ & 370 & $9^{\circ} 01^{\prime} \mathrm{S}-34^{\circ} 51.2^{\prime} \mathrm{W}$ & Brazil \\
\hline Marion Dufresne MD-55 & CB103 & $1 / 6 / 1987$ & $200-217$ & $23^{\circ} 36.4^{\prime} \mathrm{S}-42^{\circ} 01.7^{\prime} \mathrm{W}$ & Brazil \\
\hline Valdivial & P7 & $21 / 5 / 1982$ & $234-243$ & $26^{\circ} 11^{\prime} \mathrm{S}-6^{\circ} 19^{\prime} \mathrm{E}$ & Walvis Ridge \\
\hline Meiring Naudé & SM232 & $25 / 6 / 1979$ & $560-620$ & $32^{\circ} 14.9^{\prime} \mathrm{S}-29^{\circ} 10.4^{\prime} \mathrm{E}$ & E South Africa \\
\hline Meiring Naudé & ZA14 & $7 / 7 / 1987$ & 500 & $26^{\circ} 55.5^{\prime} \mathrm{S}-32^{\circ} 56.8^{\prime} \mathrm{E}$ & E South Africa \\
\hline Meiring Naudé & $\mathrm{ZA} 21$ & $8 / 6 / 1987$ & 50 & $26^{\circ} 54.8^{\prime} 5 \mathrm{~S}-32^{\circ} 55.0^{\prime} \mathrm{E}$ & E South Africa \\
\hline Anton Bruun IIOE-7 & $371 \mathrm{E}$ & $18 / 7 / 1964$ & 132 & $24^{\circ} 46^{\prime} \mathrm{S}-35^{\circ} 20^{\prime} \mathrm{E}$ & Mozambique \\
\hline Vityaz & 2733 & $18 / 12 / 1988$ & $750-755$ & $33^{\circ} 23^{\prime} \mathrm{S}-44^{\circ} 06^{\prime} \mathrm{E}$ & Madagascar \\
\hline Marion Dufresne MD-30 & DC129 & $16 / 2 / 1982$ & 525 & $46^{\circ} 06^{\prime} \mathrm{S}-49^{\circ} 17^{\prime} \mathrm{E}$ & Crozet \\
\hline Marion Dufresne MD-50 & DC114 & $19 / 7 / 1986$ & 160 & $39^{\circ} 00.5^{\prime} \mathrm{S}-77^{\circ} 46.37^{\prime} \mathrm{E}$ & St. Paul \\
\hline $\begin{array}{l}\text { Marion Dufresne MD-50 } \\
\text {. }\end{array}$ & CP145 & $22 / 7 / 1986$ & $825-1020$ & $38^{\circ} 40.66^{\prime} \mathrm{S}-77^{\circ} 35.47^{\prime} \mathrm{E}$ & St. Paul \\
\hline Marion Dufresne MD-32 & $\mathrm{DC} 27$ & $16 / 8 / 1982$ & $290-310$ & $21^{\circ} 22.2^{\prime} \mathrm{S}-55^{\circ} 46.5^{\prime} \mathrm{E}$ & Reunion \\
\hline Marion Dufresne MD-32 & $\mathrm{DR} 62$ & $22 / 8 / 1982$ & $630-710$ & $21^{\circ} 08.7^{\prime} \mathrm{S}-55^{\circ} 11.8^{\prime} \mathrm{E}$ & Reunion \\
\hline Marion Dufresne MD-32 & FA96 & $28 / 8 / 1989$ & $350-750$ & $19^{\circ} 41.5^{\prime} \mathrm{S}-54^{\circ} 08.3^{\prime} \mathrm{E}$ & Reunion \\
\hline Marion Dufresne MD-32 & FA117 & $31 / 8 / 1982$ & $450-540$ & $20^{\circ} 51.5^{\prime} \mathrm{S}-55^{\circ} 08.5^{\prime} \mathrm{E}$ & Reunion \\
\hline Marion Dufresne MD-32 & FA119 & $1 / 9 / 1989$ & $708-720$ & $20^{\circ} 52.2^{\prime} \mathrm{S}-55^{\circ} 05.9^{\prime} \mathrm{E}$ & Reunion \\
\hline Marion Dufresne MD-32 & FA137 & $3 / 9 / 1982$ & $940-980$ & $20^{\circ} 45.8^{\prime} \mathrm{S}-55^{\circ} 35.6^{\prime} \mathrm{E}$ & Reunion \\
\hline Albatross & 5312 & 4.11 .1908 & 256 & $21^{\circ} 30^{\prime} \mathrm{N}-116^{\circ} 32^{\prime} \mathrm{E}$ & E China Sea \\
\hline Vauban Musorstom-1 & 32 & $23 / 3 / 1976$ & $184-194$ & $14^{\circ} 02.2^{\prime} \mathrm{N}-120^{\circ} 17.7^{\prime} \mathrm{E}$ & Philippines \\
\hline Coriolis Musorstom-3 & 126 & $4 / 6 / 1985$ & 266 & $11^{\circ} 49.2^{\prime} \mathrm{N}-121^{\circ} 22.1^{\prime} \mathrm{E}$ & Philippines \\
\hline
\end{tabular}




\begin{tabular}{|c|c|c|c|c|c|}
\hline Danish Exp Kei Isl & 25 & 16.4 .1922 & 85 & $5^{\circ} 34^{\prime} 20^{\prime \prime} \mathrm{S}-132^{\circ} 55^{\prime} \mathrm{E}$ & Indonesia \\
\hline Vauban & 475 & $2 / 3 / 1985$ & $415-460$ & $18^{\circ} 35.7^{\prime} \mathrm{S}-163^{\circ} 11.2^{\prime} \mathrm{E}$ & New Caledonia \\
\hline Jean Charcot Biocal & DW6 4 & $3 / 9 / 1985$ & 250 & $24^{\circ} 47.93^{\prime} \mathrm{S}-168^{\circ} 09.12^{\prime} \mathrm{E}$ & New Caledonia \\
\hline Jean Charcot Biogeocal & DW253 & $16 / 4 / 1987$ & $310-315$ & $21^{\circ} 31.75^{\prime} \mathrm{S}-166^{\circ} 28.7^{\prime} \mathrm{E}$ & New Caledonia \\
\hline Jean Charcot Biogeocal & DW307 & $1 / 5 / 1987$ & $470-480$ & $20^{\circ} 35.38^{\prime} \mathrm{S}-166^{\circ} 55.25^{\prime} \mathrm{E}$ & New Caledonia \\
\hline Coriolis Chalcal-2 & DW78 & $30 / 10 / 1986$ & 233 & $23^{\circ} 41.30^{\prime} \mathrm{S}-167^{\circ} 59.60^{\prime} \mathrm{E}$ & New Caledonia \\
\hline Le Suroit Calsub & $14 / 1029$ & $5 / 3 / 1989$ & 500 & $20^{\circ} 38^{\prime} \mathrm{S}-165^{\circ} 56.6^{\prime} \mathrm{E}$ & New Caledonia \\
\hline Le Suroit Calsub & $16 / 1031$ & $7 / 3 / 1989$ & $400-500$ & $20^{\circ} 37.8^{\prime} \mathrm{S}-167^{\circ} 02^{\prime} \mathrm{E}$ & New Caledonia \\
\hline Vauban Musorstom-4 & DW162 & $16 / 9 / 1985$ & 525 & $18^{\circ} 35.0^{\prime} \mathrm{S}-163^{\circ} 10.3^{\prime} \mathrm{E}$ & New Caledonia \\
\hline Coriolis Musorstom-5 & DW299 & $11 / 10 / 1986$ & $360-390$ & $22^{\circ} 47.70^{\prime} \mathrm{S}-159^{\circ} 23.70^{\prime} \mathrm{E}$ & New Caledonia \\
\hline Coriolis Musorstom- & DW304 & $12 / 10 / 1986$ & $385-420$ & $22^{\circ} 10.34^{\prime} \mathrm{S}-159^{\circ} 25.51^{\prime} \mathrm{E}$ & New Caledonia \\
\hline Alis Musorstom-6 & DW394 & $13 / 2 / 1989$ & 570 & $20^{\circ} 49.64^{\prime} \mathrm{S}-167^{\circ} 09.11^{\prime} \mathrm{E}$ & New Caledonia \\
\hline Alis Musorstom-6 & DW397 & $13 / 2 / 1989$ & 380 & $20^{\circ} 47.35^{\prime} \mathrm{S}-167^{\circ} 05.17^{\prime} \mathrm{E}$ & New Caledonia \\
\hline Alis Musorstom-6 & DW399 & $14 / 2 / 1989$ & 282 & $20^{\circ} 41.80^{\prime} \mathrm{S}-167^{\circ} 00.20^{\prime} \mathrm{E}$ & New Caledonia \\
\hline Alis Musorstom-6 & DW 400 & $14 / 2 / 1989$ & 270 & $20^{\circ} 42.18^{\prime} \mathrm{S}-167^{\circ} 00.40^{\prime} \mathrm{E}$ & New Caledonia \\
\hline Alis Musorstom- 6 & DW 402 & $14 / 2 / 1989$ & 520 & $20^{\circ} 30.27^{\prime} \mathrm{S}-166^{\circ} 49.28^{\prime} \mathrm{E}$ & New Caledonia \\
\hline Alis Musorstom-6 & DW 407 & $15 / 2 / 1989$ & 60 & $20^{\circ} 40.70^{\prime} \mathrm{S}-167^{\circ} 06.60^{\prime} \mathrm{E}$ & New Caledonia \\
\hline Alis Musorstom-6 & DW 410 & $15 / 2 / 1989$ & 490 & $20^{\circ} 38.05^{\prime} \mathrm{S}-167^{\circ} 06^{\prime} \mathrm{E}$ & New Caledonia \\
\hline Alis Musorstom-6 & DW 416 & $16 / 2 / 1989$ & 343 & $20^{\circ} 42.15^{\prime} \mathrm{S}-166^{\circ} 59.60^{\prime} \mathrm{E}$ & New Caledonia \\
\hline Alis Musorstom- 6 & $\mathrm{CP} 455$ & $20 / 2 / 1989$ & 260 & $21^{\circ} 00.65^{\prime} \mathrm{S}-167^{\circ} 26.08^{\prime} \mathrm{E}$ & New Caledonia \\
\hline Alis Musorstom- 6 & DW 459 & $20 / 2 / 1989$ & 425 & $21^{\circ} 01.39^{\prime} \mathrm{S}-167^{\circ} 31.47^{\prime} \mathrm{E}$ & New Caledonia \\
\hline Alis Musorstom-6 & $\mathrm{CP} 464$ & $21 / 2 / 1989$ & 430 & $21^{\circ} 02.30^{\prime} \mathrm{S}-167^{\circ} 31.60^{\prime} \mathrm{E}$ & New Caledonia \\
\hline Alis Musorstom-6 & $\mathrm{CP} 468$ & $21 / 2 / 1989$ & 600 & $21^{\circ} 05.86^{\prime} \mathrm{S}-167^{\circ} 32.98^{\prime} \mathrm{E}$ & New Caledonia \\
\hline Alis Musorstom- 6 & DW 473 & $22 / 2 / 1989$ & 236 & $21^{\circ} 08.80^{\prime} \mathrm{S}-167^{\circ} 55.50^{\prime} \mathrm{E}$ & New Caledonia \\
\hline Alis Musorstom-6 & DW 474 & $22 / 2 / 1989$ & 260 & $21^{\circ} 08.80^{\prime} \mathrm{S}-167^{\circ} 55.50^{\prime} \mathrm{E}$ & New Caledonia \\
\hline Alis-Musorstom-6 & DW483 & $23 / 2 / 1989$ & 600 & $21^{\circ} 19.80^{\prime} \mathrm{S}-167^{\circ} 47.80^{\prime} \mathrm{E}$ & New Caledonia \\
\hline Vauban SMIB-3 & DW18 & $23 / 5 / 1987$ & 338 & $23^{\circ} 41.5^{\prime} \mathrm{S}-167^{\circ} 59.4^{\prime} \mathrm{E}$ & New Caledonia \\
\hline Alis SMIB-4 & DW3 7 & $7 / 3 / 1989$ & $515-540$ & $24^{\circ} 54.50^{\prime} \mathrm{S}-168^{\circ} 22.30^{\prime} \mathrm{E}$ & New Caledonia \\
\hline Alis SMIB-4 & DW39 & $7 / 3 / 1989$ & $525-560$ & $24^{\circ} 56.20^{\prime} \mathrm{S}-168^{\circ} 21.50^{\prime} \mathrm{E}$ & New Caledonia \\
\hline Al is-SMIB-4 & DW53 & $9 / 3 / 1989$ & 270 & $23^{\circ} 40.1^{\prime} \mathrm{S}-167^{\circ} 59.09^{\prime} \mathrm{E}$ & New Caledonia \\
\hline Alis SMIB-5 & DW71 & $7 / 3 / 1989$ & 265 & $23^{\circ} 41.30^{\prime} \mathrm{S}-168^{\circ} 00.70^{\prime} \mathrm{E}$ & New Caledonia \\
\hline Alis-SMIB-5 & DW101 & $14 / 2 / 1989$ & 270 & $23^{\circ} 21.1^{\prime} \mathrm{S}-168^{\circ} 04.9^{\prime} \mathrm{E}$ & New Caledonia \\
\hline Alis SMIB-8 & DW169 & 29/1/1993 & $447-450$ & $23^{\circ} 37^{\prime} \mathrm{S}-167^{\circ} 42^{\prime} \mathrm{E}$ & New Caledonia \\
\hline $\mathrm{NZOI}$ & C527 & $10 \cdot 9 \cdot 1960$ & 508 & $32^{\circ} 30^{\prime} \mathrm{S}-179^{\circ} 12^{\prime} \mathrm{W}$ & Kermadec \\
\hline S.P. Lee L3-84-SP & $21-8$ & $4 / 1984$ & 700 & $24^{\circ} 56^{\prime} \mathrm{S}-176^{\circ} 38^{\prime} \mathrm{W}$ & Tonga \\
\hline
\end{tabular}

URL: http://mc.manuscriptcentral.com/talc E-mail: steve.mcloughlin@nrm.se 